\title{
Pride and Prejudice. Ethnicized education: downgraded minorities and the Nordic channels of sacial mobility
}

\section{Julia Szalai and Claire Schiff (eds.) (2014) Migrant, Roma and Post- Colonial Youth in Education across Europe. Being 'Visibly different'. Palgrave MacMillan.}

Bourdieu starts his chapter on schooling and the inheritance of social position in La misère du monde with a quote from Herodotus about the Persian educational system (Bourdieu, 1993: 1091). Comparative educational studies are indeed way older than social sciences themselves. The volume edited by Júlia Szalai and Claire Schiff is part of this ancient tradition, while it renews it in many ways.

At the intersection of sociology and anthropology, quantitative and qualitative methods, education research and minority studies, this book examines the fate of ethnically stigmatized children in the school system and tries to answer a simple question with manifold answers: 'What does it mean to be an ethnic minority student in Europe today?' (p. 1). Let us insist, before we go into detail, that most of the authors in this book rightly understand ethnicity as a phenomenon inextricably combined with class, as the definition of segregation as ethnosocial segregation by Vera Messing shows: ethnosocial segregation is 'the situation when the school's composition is characterised by an intersection of students' ethnic minority belonging and low social status' (Messing, p. 18). Hence, the concept of class (e.g. involving ethnic relations within and between 'working class communities'; Szalai, p. 70), which is often lacking in post-1989 social scientific texts from the Central/Eastern European region, becomes an essential part of the analysis.

As a shared achievement of the participants of the 'Edumigrom Project, Ethnic Differences in Education and diverging prospects for Urban Youth in an Enlarged Europe', supported by the EU's $7^{\text {th }}$ Framework Program, this handbook is composed of three parts. To simplify, the first part uses sociological approaches, mixing quantitative and qualitative methods; the shorter second part applies an anthropological/ethnographic lens to various fields; while part three presents case studies (England, France, Germany, Romania, and Slovakia). Finally, Júlia Szalai - in her 'conclusions' - opens up new perspectives and reframes the problem in terms of citizenship and human dignity.

More than any other subject, the fate of Roma/disadvantaged children has been at the center of East and Central European social sciences, from Bulgaria (Grekova, 2002 and Kyuchukov, 2006) to Hungary - Budapest being the capital city of this research (for an extensive English-language bibliography of Bulgarian, Czech, Hungarian, Polish and Slovakian anthropological literature about schools, see Eröss, 
2012). Hungarian social researchers have also been especially dedicated to this topic (from Havas, Kemény, Ladányi and Szelényi through Kertesi and Kézdi to Zolnay, Berényi, Berkovits, Eröss, Kende and Neumann, as well as the Hungarian authors of this book). The volume extends this tradition to the whole continent, merging 'neoMarxist theories' that consider 'the role of schooling in [...] the reproduction of inequalities and marginal positions' with 'ethnographic investigations of youth subcultures'. The book explicitly aims to 'fill in this gap' between Roma studies that we know of and practice in Central Europe on the one hand, and the 'ethnographic approach and the neo-Marxist paradigm of British cultural studies' on the other (Feischmidt, p. 120.)

'Visibly different' students aged between 14 and 17 , their structural position and everyday school life in eight different countries, as well as Roma in Hungary, Romania, Slovakia and the Czech Republic, and second- and third-generation postcolonial and immigrant minorities in France, England, Germany, Sweden and Denmark were investigated. A unified survey questionnaire was administrated to over 5,000 students in over 100 schools, while in-depth interviews, focus group discussions and ethnographic observations were also conducted. However, one wishes for an explanation of the sampling technique, which included school settings with at least 'one third' of the student body being 'visibly different' (Schiff, p. 1), and may have led the researchers to overestimate school segregation and the occultation of effective integration patterns. As for segregation, it is presented as generally negative, with notable exceptions such as cases 'when separation from the majority occurs on a voluntary basis, expressed in various forms of religious or ethnic pride, in certain cases of Muslim students in Western Europe or the Gabor Gipsies in Romania' (Neményi and Vajda, p. 108).

As a worthwhile effort to move beyond the transnational studies we are used to reading which employ quantitative comparisons and/or series of case studies, the reviewed volume illustrates patterns that are common to (and differences between) Roma and immigrant youth in the 'two halves' of Europe, combining virtually all methods known to social scientists. Based on Ogbu's distinction between (voluntary) immigrant and (involuntary) racialized minorities in the US (Schiff, p. 3) the authors albeit implicitly - agree that Roma in ECE are even more oppressed than immigrants in Western countries, while the extreme Roma segregation in the Czech Republic and Slovakia tends to confirm this otherwise bold claim.

One of the major sources of originality in the book is how it addresses students' own experiences, as well as 'the differences and the relations between minority and majority pupils who actually attend the same schools', and 'who are therefore real-life peers' (Schiff, p. 3), including practices of insult and teasing (Feischmidt, pp. 130-132) and sexual relations (Neményi and Vajda, p. 113), while the topic of interracial friendships, a focal point of the increasingly dominant network analysis approach, remains relatively untouched in this book, although Moldenhawer mentions this key element by commenting on: "the importance of having what they [members of a minority] call "the right friends" [and an] aware[ness] of the importance of doing well in school' (p. 140).

Beyond the East-West divide, a triple classification of minority students is employed. This involves Roma pupils in Central Europe, postcolonial youth in 
Britain and France, and finally, the work migrants and their descendants in countries like Germany, Sweden and Denmark. A paradoxical understanding of Sweden and Denmark prevails throughout the book, emerging as soon as in the first chapter by Claire Schiff whereby it is stated that: 'In Denmark and Sweden, despite the high degree of segregation in several of the schools observed and the prevailing inequalities [...], minority pupils did not express feelings of being stigmatised or discriminated against [...]' while the school creates 'a protective microcosm where the belief in equal opportunity and the promises of the welfare state are embraced by most students'. Similarly, Vera Messing notes that even in segregated schools segregation does not have such a devastating impact because 'teachers are aware of the special needs of their students and make conscious efforts to adapt the ways of instruction to such conditions [...] but they do this without stigmatising their students' (Messing, p. 26). Júlia Szalai also identifies good practices characteristic of the Scandinavian model, both within and outside school: 'Such a strong awareness of citizenship rights helps minority adolescents to engage in personal struggles for recognition: they successfully negotiate needs for extra attention and support [...], despite recent cuts in welfare spending and the rise of anti-immigrant sentiments in both countries, their welfare states are still strong enough to provide support for familial advancement' (Szalai, p. 76). Szalai - and indeed the whole book - makes a case for the Scandinavian model; a combination of citizenship (individual and collective rights as citizens) and the welfare state (a mix of educational but also social, health and employment policies). Empirical support for this is provided by Schnell and Crul: 'Second generation Turks in Sweden more often achieve higher educational levels than their counterparts in the two other countries [Austria and the Netherlands], even if their parents are from similar educational background' (Schnell and Crul, pp. 40-41). Once more, Violetta Zentai presents Sweden as a champion: 'Sweden stands out as a pioneer on both grounds [educational stratification/equalisation policy and complex multicultural policy] followed by the UK, which makes deliberative efforts to offer citizenship by acknowledging difference and making efforts to ensure equal opportunities in schooling' (Zentai, p. 89).

As a logical consequence of in-depth field work, the book deconstructs essentialist misconceptions about ethnicity and otherness; it shows that in England 'tensions more often opposed British Afro-Caribbean and Asian students than majority and minority students', and mentions the negative stereotypes related to partially racialized subcultures such as emos and chavs (Law and Swann, p. 159). Continuing down the path of deconstructing essentialism, several authors insist on the hybridity of identity strategies 'which combine the desire for integration with the will to remain separated from the outer world' (Vincze, pp. 204-205), 'the categorization among Roma pupils' (Kostlán, p. 223), or the even more detailed observation of specific strategies of specific subgroups at the intersection of ethnicity, class and gender and in the context of given educational settings such as of female students' Maghreb parents' willingness to succeed (Szalai, p. 77), or, on the contrary, the issue of participation in class trips for Muslim girls: 'Often girls are not allowed to participate in class trips, although they are obligatory [...]’ (Straßburger, p. 193.)

In terms of citizenship, the call by Szalai for the participation of both the welfare state and citizen rights (i.e., collective rights as a guarantee of equal 
opportunities in education) is clear, and is supported by a French case study which shows that treating ethnicity as taboo does not necessarily result in equal opportunities for students with an ethnic/immigrant background, but the opposite in a school system which makes a point of ignoring their cultural and ethnic characteristics [while] certain minority groups are clearly over-represented among students enrolled in the least desirable schools and streams' (Schiff, p. 62). To restate an apparent truism with multiple consequences and complex patterns, 'ignorance-based policies' (Eröss, 2009) are, unsurprisingly, seldom successful in tackling inequalities. As a matter of fact, Vera Messing also underlines in her chapter that school systems that combine segregation with diversity-blind school policies score most purely in terms of minority children's educational achievement.

While it has been a common understanding of many trans-European research papers that Roma in Central Europe and immigrants in Western Europe are victims of similar structural oppression, including in the school system (be this ethnic segregation or segregation based on so-called 'special educational needs'), no systematic research has, until this volume, tried to grasp the complexity of the phenomenon and the patterns of minority pupils' segregation/integration across Europe. This makes the reviewed book a reference for generations of sociologists, anthropologists, education and minority studies researchers to come. It also delivers a strong, evidence-based message to decision-makers: follow the Scandinavian model of promoting social mobility for minorities through the school system, which is based on a combination of individual help, 'language support, upgrading the knowledge of minority students to the majority culture and applying practices for enhancing selfconfidence' (Messing, p. 26), as well as collective rights, recognition, dignity and citizenship; more precisely, a synthesis of support for ethnic identity and the emancipatory values of the welfare state. 'Schools cannot escape their role in informing young people's identities as a core content of their citizenship' (Szalai, p. 243) and transforming, in the long term, ethnosocial segregation into - and here let us use a neologism - ethno-civic integration.

\section{Gábor Erőss (Eross. Tabor回tk.mta.hu) Center for Social Sciences, Hungarian academy of Sciences}

\section{References}

Berkovits, B. and Oblath, M. (2008) A gyógypedagógiától a szociológiáig és tovább: A fogyatékosság és a szociális hátrány kapcsolatainak diskurzusa és politikája (English: From Special Education to Sociology and Beyond: Discourse and Policy of Relationships to Disability and Social Disadvantage). In: Berényi, E., Berkovits, B., Erőss, G. (2008) Iskolarend: Kiváltság és Különbségtétel a közoktatásban (English: School System: Privilege and Distinction in Public Education.) Budapest: Gondolat Kiadó. 21-48. 
Bourdieu, P. (ed.) (1993) La misère du monde (English: The Misery of the World). Paris: Seuil.

Erőss, G (2008) Különbség és szórás: Kategorizációs és szelekciós finommechanizmusok az oktatásban: SNI-k, lókötők és társaik (English: Difference and Dispersion: Categorizational and Selectional Fine Mechanisms in Education: SENs, Good-for-Nothings and Others. In: Eröss, G. and Kende, A. (eds.) Túl a szegregáción: Kategóriák burjánzása a közoktatásban (English: Beyond Segregation: Proliferation of Categories in Public Education). Budapest: L'Harmattan. 157-234.

Erőss, G. (2009) Ignoranz, die Wissen erzeugt: "Spezifiziertes Nichtwissen” und Wissensersatzmechanismen im Spiegel des ungarischen Gesundheits- und Schulwesens. Soziale Welt - Zeitschrift für sozialwissenschaftliche Forschung und Praxis, 60(4): 371-387. DOI: https://doi.org/10.5771/0038-6073-2009-4371

Erőss, G (2012) Central Europe: Bulgaria, the Czech Republic, Hungary, Poland, Romania, Slovakia. In: Kathryn M. Anderson-Levitt (ed.) Anthropologies of Education: A Global Guide to Ethnographic Studies of Learning and Schooling. New York; Oxford: Berghahn Books. 167-192.

Grekova, M. (1999) Cultural Difference as a Problem of Intercultural Education. In: de Keersmaeker, G. and Makariev, P. (eds.) Bulgaria - Facing Cultural Diversity. Sofia: IPIS, ACCESS.

Havas, G. (2002) The School as Breakout Point. In: Kállay, E. (ed.) The Gypsies/the Roma in Hungarian Society. Budapest: Teleki László Foundation. 79-106.

Kende, A. (2008) A rugalmas beiskolázás szerepe az oktatási szakadék elmélyülésében. Pszichológiai és szociológiai érvek egy oktatáspolitikai intézkedés kapcsán (English: The Role of Flexible Schooling in Deepening the Educational Gap. Psychological and Sociological Arguments in Relation to an Educational Policy Measure). In Erőss, G. and Kende, A. (eds.) Túl a szegregáción: Kategóriák burjánzása a közoktatásban (English: Beyond Segregation: Proliferation of Categories in Public Education). Budapest: L'Harmattan. 105-136.

Kemény, I., Janky, B. and Lengyel, G. (2004) A magyarország cigányság 1971-2003 (English: The Hungarian Gypsies 1971-2003). Budapest: Szociológiai Intézet.

Kertesi, G. and Kézdi, G. (2013) School Segregation, School Choice and Educational Policies in 100 Hungarian Towns. In: Budapest Working Papers of the Labour Market BWP, 2013/12, http://www.econ.core.hu/file/download/bwp/bwp1312.pdf

Kyuchukov, H. (2006) Desegregation of Roma schools in Bulgaria. Sofia: S.E.G.A.

Ladányi, J. and Szelényi, I. (2001). The Social Construction of Roma Ethnicity in Bulgaria, Romania and Hungary During Market Transition. Review of Sociology, 7(2), 79-89. DOI: https://doi.org/10.1556/revsoc.7.2001.2.5 
Neumann, E. (2017) 'Fast and Violent Integration': School Desegregation in a Hungarian Town. Race Ethnicity and Education, 20(5): 579-594. DOI: https://doi.org/10.1080/13613324.2016.1191696

Zolnay, J. (2006) Kényszerek és választások. Oktatáspolitika és etnikai szegregáció Miskolc és Nyíregyháza általános iskoláiban (English: Compulsions and Choices. Education Policy and Ethnic Segregation in the Primary Schools in Miskolc and Nyíregyháza). Esély, 4. 